\title{
PREFACE
}

\section{TIMOTHY ENDICOTT}

The papers published in this issue were delivered at a Symposium on Vagueness and Law at Columbia U niversity Law School on September 24 and 25, 1999. The purpose of the seminar was to provide an opportunity for philosophers of law, philosophers of language, and philosophers of logic to discuss problems about vagueness that are currently under debate in all three areas.

The nature and implications ( and even the existence) of indeterminacy in the requirements of the law have been important issuesin the philosophy of law. Some legal theorists have argued that the language with which legislators frame laws (and with which judges and other lawyers state the law) is typically vague, and that its vagueness means that the requirements of the law must be indeterminate in some cases. Others have rejected both claims. The issue is consequential for an understanding of law, because it raises fundamental questions about the role of judges and about the rule of law: if judges are not giving effect to the legal rights of the parties in some cases, then what are they doing, and how can it be justified? And how can a community achieve the ideal of the rule of law if the requirements of the law are indeterminate?

The fascination of philosophers of logic with the paradox of the heap has recently generated sophisticated controversies that bear on those questions of legal theory. Philosophers of logic argue about the soundness and the scope of the principle of bivalence-the principle that every statement is either true or false. Some philosophers of logic have attempted to defend that principle and to apply it generally to all meaningful discourse; others have constructed nonclassical logics or semantics to account for the application of vague words as indeterminate in some cases. The challenge to philosophy of language is either to explain how there could be right answers to all questions of the application of ordinary vague words, or else to show just how that notion is misconceived (and what is left of logic if it is misconceived).

So philosophers of law, philosophers of logic, and philosophers of language may all be able to contribute to important controversies about indeterminacy in the application of language-at least, potentially. It will be seen from the papers presented here that a major issue of discussion at the symposium was the extent to which the work of philosophers of logic relates to the concerns of legal philosophy.

The authors are grateful to the Center for Law and Philosophy at Columbia for making the symposium possible and to the participants in the symposium for their comments. 